\title{
MAGE-A3 Peptide Vaccine
}

National Cancer Institute

\section{Source}

National Cancer Institute. MAGE-A3 Peptide Vaccine. NCI Thesaurus. Code C91710.

A peptide cancer vaccine comprised of a peptide derived from the human melanoma antigen A3 (MAGE-A3), with potential immunostimulating and antineoplastic activities. Upon administration, MAGE-A3 peptide vaccine may stimulate the immune system to mount a cytotoxic T-cell (CTL) response against tumor cells expressing MAGE-A3, resulting in tumor cell lysis. MAGE-A3, a tumor-associated antigen (TAA), is overexpressed by a variety of cancer cell types. 